\title{
COLONEL FREDERICK SMITH, C.B., C.M.G., D.S.O.
}

M. DAVIES, Librarian

Royal Army Medical College

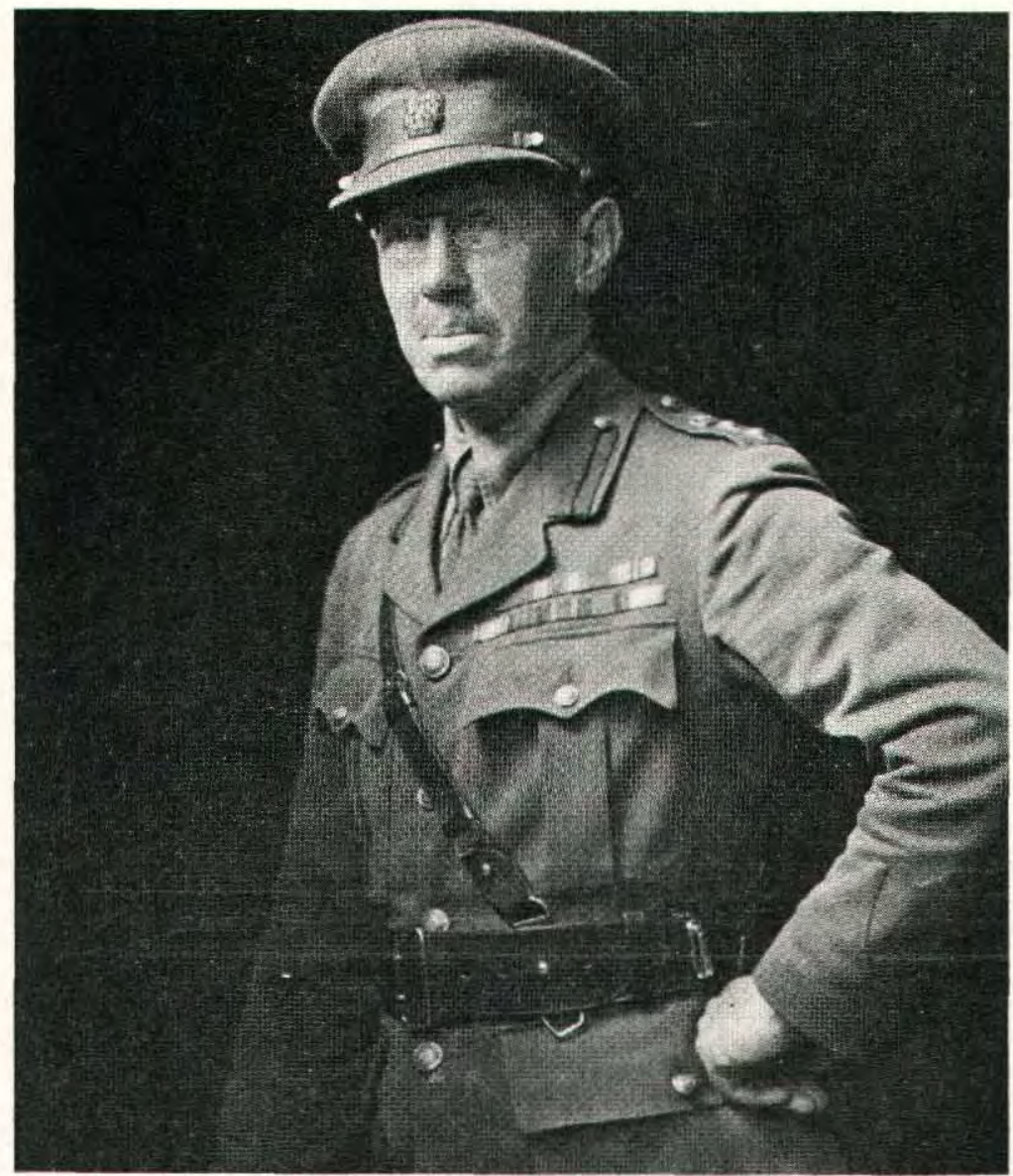

FREDERICK SMITH (1858-1933)

Although the name of Fred Smith was well known to officers of an earlier generationmainly on account of his "A Short History of the R.A.M.C." (1929) - it is one quite unknown to-day. This is to be regretted as Smith was indeed a "lad o' pairts " as he started his Army career as a Private in the Army Hospital Corps and obtained a medical degree whilst still an other rank and then a Commission as a Medical Officer-surely a quite unique achievement? It was to rescue him from his undeserved obscurity that the present biographical sketch was undertaken.

Smith was born at Horncastle, Lincolnshire on the 14th February 1858 and was one of several sons all of whom ran away from home because of a tyrannical father. All made names for themselves. 
He was a pupil of the Burgh Middle School where he did well gaining a First Class Certificate of Education and also a First Class in Latin.

His Army career began when at the age of eighteen he joined the Army Hospital Corps as a Private in 1877 and served as an other rank for twelve and a half years. He saw considerable service taking part in the Zulu War of 1879 and the First Boer War of 1881 .

In 1886 he had risen to Non-Commissioned rank, and was stationed in Dublin. There he registered as a Medical Student and attended medical classes.

The Royal Warrant for 27th November 1879 laid down that half the vacancies in the Army Medical Department might be filled by candidates recommended by the governing bodies of the medical schools in Great Britain. Colonel Smith was, we believe, the only officer ever appointed under these conditions(1).

In 1889 he obtained the licences of the Irish Colleges, these colleges recommending him for a Commission in the Army. The same year he received the Diploma of the Royal College of Physicians and Surgeons in Ireland.

The recommendation for a Commission was accepted and in 1890 Smith attended the Surgeons on Probation Course at Netley. When the results of this course were published we read " Fred Smith 1st Class Staff Sergeant Medical Staff Corps 2803 (Netley marks only) gained the Herbert Prize of $£ 20$ with the Montefiore second prize ". As the result of his excellent record he was appointed Surgeon Captain in the same year (1890). Much of his work as a Medical Officer was related to the Army Health field and the following is a brief outline of his Commissioned Service.

In 1891 he was posted to the Strait Settlements where he remained until 1896. From 1896 to 1898 he worked at Netley as assistant in the Bacteriological Laboratory. In 1897 he gained the D.P.H. Durham and the Parkes Memorial Medal. In Sierra Leone in 1898-99 he took part in the operations in the Mendi and Protectorate expeditions, receiving the Medal and Clasp.

During the South African War (1899-1901) he took part in the operations in the Orange Free State: the Orange River Colony and the Transvaal including action at Biddulphsbery, Bethleham, Wittehergan and in Cape Colony. He was mentioned in despatches, receiving the D.S.O. and Queen's Medal with four Clasps.

In 1903 he gained the Alexander Prize Essay Gold Medal (again in 1906), and the Enno Saunder Gold Medal of the United States Army.

In 1907 he served on the North West Frontier of India as staff officer to the Principal Medical Officer during the Mohmand Expedition, receiving a Medal with Clasp.

In the 1914-18 War he was Officer Commanding, Trianon Palace. Hospital and Senior Medical Officer, Paris area 1914; Assistant Director of Medical Services 27th Division 1915; and Deputy Director of Medical Services 16th Corps 1917-1918. He was appointed C.B. and C.M.G., receiving the 1914-1918 Star, British War Medal and Victory Medal.

During his many tours abroad Colonel Smith sent many specimens of plants, insects etc. to his friends and to institutions in England-Sir Ronald Ross, E. E. Austen, Kew Gardens, the British Museum and many other private collectors. Anopheles smithii was collected by him, and named after him. 
His publications were many and covered a wide field. His book on "Modern Bullet Wounds" was translated into Chinese.

He retired after World War I but continued to take an active interest in medicine and in the Corps. It was during this period that he wrote his History.

When we consider the achievement his medical degree and commission represent, the success of his military career culminating as D.D.M.S. of a Corps, and his clinical work as evidenced by the biographical sketch which we publish can one doubt that he is one of our Corps who should be better known?

Much of the above information on which this sketch is based came from his sonthe late Dr. Hector Smith-who presented in 1957, some of his father's papers to the R.A.M.C. Historical Museum.

\section{Editorial Note}

As we go to press we are glad to record that the Curator of the R.A.M.C. Historical Museum who "discovered" Smith independently of Mr. Davies informs us that Colonel Fred Smith and his unique career are being given a special display in the Museum.

1. Brit: med. J. ii (1933) p.402.

\section{REFERENCE}

\section{COLONEL FREDERICK SMITH BIBLIOGRAPHY}

1897 (with Wright, A. E.) A note of the occurrence of Malta fever in India. Brit. med. $J . i, 911$.

1897 On the application of serum diagnosis to the investigation of the origin of epidemics as exemplified by Maidstone outbreak. Brit. med. J. ii, 1118.

1897. (with Wright, A. E.) On the application of the serum list to the differential diagnosis of typhoid and Malta fever. Lancet $i, 656$.

1898 Report on the Mendi Expedition and occupation of Sherbro, Sierra Leone, 1898. Report on the Health of the Army 40, 462-466.

1898 Malaria: Immunity: Absence of negro immunity: variety, as illustrated by the incidence of the disease on various races in Sierra Leone. Brit. med. J. ii, 1807.

1899 Ankylostoma in Sierra Leone. Brit. med. J. ii, 1543.

1900 Waterberg Hot Springs, Warmbab, Transvaal. Brit. med. J. ii, 1465.

1900 The distribution of mosquito larvae on War Department lands in Sierra Leone. Report on the Health of the Army 41, Appendix 8, 495-501.

1901 Two cases of blackwater fever with pathological notes by M. Logan Taylor. Lancet $i i, 776-7$.

1904 Modern Bullet Wounds and Modern Treatment, with Special Regard to Long Bones and Joints, Field Appliances, and First Aid (Part of the Alexander Prize Essay, 1903). Churchill, London. p.100.

1904 Also in J. Trop. Med. 7,

1904 Also (Translated) in An. San. mil. Buenos Aires 48, 195-263.

1904 Anti-typhoid or Anti-enteric innoculation (being the Lady McGrigor Prize Essay). J. Trop. Med. 7, 271-7.

1904 The differential diagnosis of typhoid fever in the earliest stages. J. Ass. mil. Surg. 14, 69 and 166.

1904 Hystencal paraplegia in the male. Brit. med. J. $i, 125-6$.

1904 Drainage, Sewerage and Conservancy in Tropical Countries and Elsewhere. (being a Belilios Prize Article). Bale, Sons \& Danielseon, London. p.92.

1904 Also in J. Trop. Med. 6, 285.

1904 What evidence can be adduced as to the conveyance of diphtheria infection from lower animals? J. roy. Army med. Cps. 2, 43-62.

1904 (with Pearse, A.) Fevers in Sierra Leone (Mount Aureol) being a preliminary account of an enquiry into the causes of the continued prevalence of ill health in an apparently favourably situated hill station. J. roy. Army med. Cps. 2, 278-282.

1904 (with Peill, S. G.) A spirillum in an acute tropical ulcer at Sierra Leone. J. roy. Army med. Cps. 3, 293-4.

1905 Tuberculosis among civilized Africans: special prevalence and fatality. J. Trop. Med. 8, 19-21.

1905 The ankylostomun, the strongylus, the tricocephalus, the ascaris, and an associated infusorian in West Africa; chiefly in regard to military inefficiency; modes of infection and life history of the parasites; also a note on an unidentified worm. J. roy. Army med. Cps. 4, 6-12, 189-205 and 335-348.

1905 Certain forms of fever and the conditions bearing thereon, in the hill stations of Sierra Leone. J. roy. Army med. Cps. 5, 688-701. 
1905 (with Smith, L. F.) A note on blackwater fever studies, in association as to the later part of the work with Captain L. F. Smith, R.A.M.C. J. roy. Army med. Cps, 5, 701-2.

1905 Aropheles Smithii (collected by F. Smith and named after him and written up by Fred. V. Theobald, M.D. in the Entomologist, 38, 101.

1906 Trypanosomiasis in Sierra Leone. J. roy. Army med. Cps. 7, 209-210.

1906 Notes from Aldershot with the 3rd Division Field Ambulance. J. roy. Army med. Cps. 7, (Corps News) 103-5.

1906 (with Copeland, R. J.) Malarial fever contracted in Portsmouth. J. roy. Army med. Cps. 7, 186-7.

1906 Mumps as an ailment of adults in the Army. Lancet ii, 191.

1906 Remarks on the history and prevalence of diphtheria in the British Army. J. roy. Army med. Cps. 7, 348-368.

1907 The soldiers heart and the civilians. J. roy. Army med. Cps. 8, 1-6.

1907 Interesting cases of primary tubercule in organs other than the lung. J. roy. Army med. Cps. 8, $295-7$.

1907 Houseflies and their ways at Benares. J. roy. Army med. Cps. 9, 150-5 and 447.

1907 The best method of forming and registering a reserve of retired officers (R.A.M.C.), civil medical men and male nurses for service (A) at home (B) abroad, on mobilisation. J, roy. Army med. Cps. 9, 98-106.

1908 Timbu fly disease in Sierra Leone. J. roy. Army med. Cps, 10, 14-5.

1908 A further note on the ways of common flies in India. J. roy. Army med. Cps. 11, 56-7.

1908 The causation of twins. J. roy. Army med. Cps. 11, 114-5.

1909 The sedimenting effects of the sera of cows on some bacilli of the typhoid group. J. roy. Army med. Cps. 13, 265-270.

1910 (with Newman, R. E. V.) A case of continued fever associated with the presence of bacillus resembling Bacillus Coli in the blood, and complicated with malaria (Rawalpindi, India). J. roy. Army med. Cps. 15, 732-3.

1911 Reaction of sera of anomalous and other fever cases to Bacillus Coli. J. roy. Army med. Cps. 16, 78.

1911 The sediment effects of the sera of horses and sheep on Bacillus Typhosus and Bacillus Coli. J. roy. Army med. Cps. 16, 196-7.

1911 (with Lishman, T. and Quick, C. F. H.) On the Widal reaction of horse's sera to typhoid bacilli. J. Trop. Ket. Sc., Calcutta 6, 156.

1912 (with Bradley, F. H.) A curious case of fever in Calcutta. J. roy. Army med. Cps. 19, $219-221$.

1912 Malarial coma mistaken for drunkenness. J. roy. Army med. Cps. 19, 463-5.

1912 (with Bradley, F. H.) Dysenteri ulceration, without dysenteri symptoms, followed by hepatic abscess. J. roy. Army med. Cps. 18, 578-9.

1913 (with Hastings, A. E. F.) Multiple neuritis among soldiers in Calcutta and vicinity-an endemic epidemic, seasonal disease resembling Ben-ben. J. roy. Army med. Cps. 20, 202-5.

1913 Dengue fever among the troops in Calcutta; its identity with seven-day fever and three-day fever. J. roy. Army med. Cps. 20, 453-8.

1914 Shakespeare on syphilis. J. roy. Army med. Cps. 22, 450.

1914 Beriberi or polyneuritis among British troops in India. J. roy. Army med. Cps. 23, 64-6.

1927 "Possessed". J. roy. Army med. Cps. 49, 102-6.

1928 A little knowledge. J. roy. Army med. Cps. 50, 34-7.

1928. Fasciola hepabica: a fatal case in a European soldier (reported by Col. Smith and written by W. L. Chester, M.B.). J. roy. Army med. Cps. 51, 463.

1929 The white man's grave in the eighteenth century. $J$. roy. Army med. Cps. 53, 398-9.

1929 A Short History of the Royal Army Medical Corps. Gale \& Polden, Aldershot: pp ix +111.

1931 Balantidium coli. J. roy. Army med. Cps. 57, 62.

\section{Central Midwives Board}

Colonel H. S. Gavourin, M.B.E., M.B., F.R.C.O.G., has been appointed Examiner to the Central Midwives Board. 